\title{
Sondażowy zawrót głowy AD 1989
}

\section{SEBASTIAN LIGARSIKI}

Instytut Pamięci Narodowej ORCID: 0000-0001-5768-6451
Trudno wyobrazić sobie kampanię wyborczą bez sondaży. Partie polityczne wciąż ustosunkowują się do nich, dostosowując swoją taktykę walki z przeciwnikiem politycznym. Nie inaczej było w czasie kampanii wyborczej przed wyborami do Sejmu PRL w czerwcu 1989 roku. 0 ile nikogo nie dziwi, że większość sondaży robiono na zlecenie Polskiej Zjednoczonej Partii Robotniczej, głównie przez Ośrodek Badań Opinii Publicznej (teraz Kantar Public TNS) oraz Centrum Badań Opinii Społecznej, o tyle wiedza o sondażach wyborczych zlecanych bądź realizowanych dla komitetów obywatelskich Solidarności nadal jest raczej niewielka ${ }^{1}$.

W dniach 15-17 maja 1989 roku badania opinii społecznej przeprowadzili w Polsce Georges Mink i Paweł Kuczyński. Zrealizowali je z pomocą CBOS, gdyż jak pisali w swoim raporcie, w tamtym okresie ,jedyną dostępną siecią ankieterów dysponowała firma «Promotor», która mimo swojej odrębności formalnej de facto była częścią CBOS"2. Próba została przeprowadzona na 1495 osobach powyżej 18 roku życia. Frekwencję wyborczą określono na 84\% i w wielu niezależnych sondażach wyborczych była ona o kilka lub kilkanaście procent wyższa od rzeczywistej $(62,3 \%)^{3}$. Natomiast złudzeń dla władzy nie pozostawiały deklaracje wyborcze dotyczące głosowania na osoby utożsamianie z tak zwaną drużyną Wałęsy lub identyfikowanych jako "solidarnościowe”. W tym badaniu w wyborach do senatu $90 \%$ miejsc miało przypaść Solidarności, co należało uznać za przewidywania niezwykle

1. 0 sondażach wyborczych dla partii zob. m.in.: T. Kisielewski, Partii portret własny. Polityka i świadomość w PZPR - studium upadku, Warszawa 2012; A. Dudek, Reglamentowana rewolucja. Rozkład dyktatury komunistycznej w Polsce 1988-1990, Kraków 2014; P. Codogni, Wybory czerwcowe 1989 roku. U progu przemiany ustrojowej, Warszawa 2012; Wyniki badań - wyniki wyborów: 4 czerwca 1989, praca zbiorowa pod red. L. Kolarskiej-Bobińskiej, P. Łukasiewicza i Z.W. Rykowskiego, Warszawa 1990; Społeczeństwo i władza lat osiemdziesiatych w badaniach CBOS, oprac. B. Badora, Warszawa 1994.

2. P. Kuczyński, Sondaż przedwyborczy dla "Le Journal des elections", [w:] Wyniki badań - wyniki wyborów..., s. 14. W rozmowie Patryka Pleskota z Georges'em Minkiem nie ma ani słowa o tym sondażu i jego realizacji. Mink wspomina o swoich wizytach w Polsce w tym czasie, udziale w zbiórkach pieniędzy dla opozycji, które trafiły do "Gazety Wyborczej", oraz o swoim zaangażowaniu w kampanię wyborczą Jacka Kuronia. Zob. P. Pleskot, Tam i z powrotem... Georges Mink w słowach, dokumentach i obrazach, Warszawa 2018.

3. P. Kuczyński, Sondaż przedwyborczy..., s. 15. 
trafne ${ }^{4}$. Jeśli chodzi o sejm, liczba głosów rozkładała się różnie w zależności od województw. Jednak w każdym przypadku ponad 50\% respondentów zdecydowanych było głosować tylko na kandydatów Solidarności. W województwie stołecznym ten odsetek sięgał aż 68\%. Co ciekawe, autorzy tego sondażu w ogóle nie brali pod uwagę innych kandydatów opozycji ${ }^{5}$.

Ciekawym zabiegiem było pytanie o przyszłego prezydenta Polski. W sondażu Lech Wałęsa i Wojciech Jaruzelski zdobyli odpowiednio 18,7\% i 18,5\% głosów Trzecie miejsce zajął Mieczysław Wilczek (15,3\%), czwarty zaś był Mieczysław F. Rakowski z $10,8 \%$ poparcia ${ }^{6}$.

Badania opinii społecznej prowadzono także w terenie. Przykładowo dla Komitetu Obywatelskiego "Solidarność" we Wrocławiu robił je Bogdan Zdrojewski. Jarosław Obremski wspominał: „do Komitetu przyszedł Bogdan Zdrojewski, który powiedział, że jest socjologiem i może zrobić badania, bo sekretarzem Komitetu Obywatelskiego był Rafał Dudkiewicz i on właściwie był tą osobą, która w całości organizacyjnie to wszystko spajała. I tak jak to Rafał - chcesz robić badania, to rób badania!"7. Przeprowadzone przez Zdrojewskiego i grupę wspomagających go osób sondaże okazały się bardzo pomocne w prowadzeniu dalszej kampanii wyborczej. Na posiedzeniu wrocławskiego Komitetu Obywatelskiego 28 kwietnia 1989 roku Zdrojewski omówił koncepcje pracy grupy socjologów w ramach Biura Badania 0pinii Publicznej i stwierdzit, że doświadczenia z kampanii wyborczej z Zachodu są nieprzystawalne do polskich realiów. Zgoda na badania dla Zdrojewskiego zaowocowała kilkoma sondażami. I tak w dniach 5-10 maja przebadano 630 osób, spośród których 149 objął sondaż uliczny oparty na kwestionariuszu, 220 wywiad ankietowy, 109 osób wyraziło opinię telefonicznie podczas sondażu dotyczącego oglądalności programu wyborczego Solidarności, 69 wypowiedziało się podczas niesformalizowanego sondażu w różnych punktach miasta, a 91 odmówiło udziału, reagując negatywnie na sam wywiad, jak również na osoby badające, które reprezentowały stronę opozycyjno-solidarnościowa 9 .

Ciekawie brzmiały informacje o składzie spoŁecznym poddanym badaniu:

"objęto nim m.in. robotników kilku zakładów pracy /Elwro, FAT/, lekarzy przychodni i szpitala, pielęgniarki szpitalne i przychodni, telefonistki i pracowników poczty, osoby przebywające na urlopach wychowawczych, kolejarzy zatrudnionych w ruchu oraz D0KP, emerytów i rencistów i sprzedawców i klientów kilku sklepów, osoby w różnych grupach wiekowych różnych dzielnic i uczestników dwóch zgromadzeń wyborczych. Z zaplanowanych badań nie uwzględniono jeszcze grupy rzemieślników, nauczycieli, średniej administracji państwowej oraz pracowników firm polonijnych oraz spółek.

Osoby reagujące negatywnie na propozycję udzielenia wywiadu ankieterom Solidarności zostały podzielone na dwie grupy (identyczne) z której pierwsza została włączona w grono osób głosujących na stronę rządową, druga natomiast powiększyła grono tych, którzy nie będą głosować lub też jeszcze tego nie wiedzą (wiedzą natomiast, iż nie będą popierać Solidarności). Grupa powyższa stanowi blisko $14 \%$ badanych" ${ }^{10}$.

4. Ibidem.

5. Ibidem, s. 13-25.

6. Ibidem, s. 21.

7. Jarosław Obrembski, autoryzowany wywiad z 2 marca 2017, przeprowadzony przez Pawła Kowalskiego, red. E. Wosik. Wywiad przeprowadzony do projektu „Dokumenty przełomu...”, por. http://dokumenty-przelomu.pl/wywiady/\#_Toc5555889 (dostęp: 28.12.2019).

8. Biblioteka Zakładu Narodowego om. Ossolińskich (dalej: BZNi0), Dział Rękopisów (Drkps), sygn. 63/91/1, Badania opinii społecznej 05-10 maja $1989 \mathrm{r}$.

9. Ibidem.

10. Ibidem. 
Udział w wyborach zadeklarowało więc $68 \%$ osób, niezdecydowanych było $24 \%$, a w wyborach miało nie wziąć udziału 7\% ankietowanych. $\mathrm{Na}$ Solidarność zadeklarowało swój głos 44\% wyborców, na jej przeciwników 22\%, niezdecydowanych było $23 \%$, różnie miało zaś głosować $11 \%{ }^{11}$. Kolejne badania zrobiono po następnych dniach intensywnej kampanii - był to chyba jeden z ostatnich sondaży robionych przed wyborami przez stronę niezależną. I tak poparcie dla Solidarności miało utrzymywać się na poziomie około 40\%, poparcie kandydatów strony koalicyjno-rządowej utrzymywało się w granicach $12-20 \%$ i wynosiło $13 \%$ dla senatu i $15-27 \%$ dla sejmu. Jak stwierdzano: „ok. 10\% społeczeństwa deklarującego chęć wzięcia udziału w wyborach i określonego głosowania popełnia błędy przekreślające ważność ewentualnie oddanych głosów (pozostawienie zbyt dużej ilości kandydatów na 1 karcie wyborczej", a "ok. 15\% pragnie podzielić głosy pomiędzy różnych kandydatów w zależności od mandatów, wykazując przy tym brak stosowania jednoznacznego kryterium". Dodawano, że "pozostałe osoby zgłaszające chęć uczestnictwa w wyborach nie deklarują określonego poparcia lub czynią to w sposób enigmatyczny. Osoby, które nie deklarują udziału w wyborach są:

a. niezdecydowane ok. $15 \%$

b. bojkotujące wybory świadomie $-2,5 \%$

c. zapowiadające brak zainteresowania wyborami $10-23 \%{ }^{\prime \prime 2}$.

Wnioski wysunięte na podstawie tych badań były bardzo konstruktywne. Uważano, że:

„W praktyce: $20 \%$ nie zna nawet nazwisk kandydatów lub też uważa, że technika głosowania jest zbyt skomplikowane, 10\% osób przekonanych o znajomości techniki głosowania popełnia błąd już w fazie deklarowania określonego poparcia w zapowiadanym głosowaniu, procedura głosowania wydaje się skomplikowana dla $40 \%$ potencjalnym wyborców, świadomy bojkot (z powodu «ograniczonej demokracji», tzn. obsadzenie każdego mandatu jednym kandydatem Solidarności) zapowiada 2-3\% (głównie młodzież), grupę popierającą stronę koalicyjno-rządową sztucznie powiększają:

a. zdezorientowani, interpretujący kandydatów PZPR jako reprezentantów opozycji (5-10).

b. deklarujący neutralność polityczną, zapowiadający głosowanie na kandydatów «mądrych», "pracowitych», «specjalistów», "porządnych obywateli» - do 17\% (powyższe osoby mogą przyczynić się do powiększenia 18\% poparcia koalicji do: $18+10+17=45 \% \mathrm{w}$ najbardziej niesprzyjających dla «Solidarności» sytuacjach, przy założeniu ważności wszystkich oddanych głosów - wydaje się, iż takie założenie jest jednak nieprawdopodobne)"13.

Według osób przeprowadzających wrocławskie sondaże najniższa frekwencja dotyczyła młodzieży, choć widziano szansę na jej aktywizację, osób starszych, szczególnie poza obszarem miast (i ta tendencja mogła się jeszcze pogłębić) oraz kobiet do 25 roku życia, zwłaszcza przebywających na urlopach wychowawczych. Wpływ na zmianę ich podejścia do wyborów mogło mieć tylko najbliższe otoczenie ${ }^{14}$. Zdrojewski w swoim podsumowaniu napisał:

"1. należy się spodziewać korekty wyników do $10 \%$ na niekorzyść «Solidarności» w wyniku wpływu okręgów zamkniętych; 2. ilość głosów nieważnych będzie miała znaczenie jedynie w przypadku nierównego ich rozłożenia pomiędzy strony; 3. niezdecydowani co do sposobu głosowania w przeważającej części stanowią grupę potencjalnych sprzymierzeńców «Solidarności», jednak ich słaba orientacja w procedurze wyborczej i nazwiskach kandydatów może przyczynić się do obniżenia uzyskanych wyników; 4. obniżenie frekwencji

11. Ibidem.

12. Ibidem, Sondaż przedwyborczy z 23 maja - 01 czerwca 1989 r.

13. Ibidem.

14. Ibidem. 
wyborczej (brak informacji o lokalizacji komisji wyborczej, złe warunki dojazdu, pogorszenie się warunków atmosferycznych) może dotyczyć tylko strony Solidarnościowej (dyscyplina partyjna nadal działa); 5. na obszarze poza miastem skład komisji może mieć wpływ samopoczucie wyborców (dyrektorzy zakładów pracy, osoby funkcyjne itp.), mogą więc pojawić się postawy konformistyczne wobec systemu; 6. lista krajowa będzie stanowiła główne źródło skupienia uwagi: zapowiedź skreślania poszczególnych osób zadeklarowało prawie $80 \%$ wyborców (w tym nieco ponad 50\% wskazuje, że żadna osoba $\mathrm{z}$ listy krajowej nie powinna w ogóle kandydować; dotyczy to przede wszystkim Miodowicza, Kiszczaka, Kani i Urbana, to ostatnie nazwisko pojawia się bardzo często podobnie jak Jaruzelskiego, który w ogóle nie kandyduje); 7. żadna z osób na mandatach koalicyjnych nie powinna uzyskać wymaganej większości głosów.

Autentyczne poparcie «Solidarności» deklaruje co trzeci respondent (35\%). Co drugi czyni to z pewną dozą ostrożności, zachowując dystans i deklarując brak zainteresowania sprawami polityki, około 15\% w rozmaity sposób wskazuje na czynne popieranie strony koalicyjno-rządowej (odmowa udzielenia wywiadu stronie Solidarnościowej, otwarta deklaracja poparcia itp.) Spośród tych, którzy deklarują poparcie dla «Solidarności» zachowując wobec niej określony dystans istnieje spora grupa osób, która takim samym poparciem jest w stanie obdarzać stronę przeciwną, jeśli sytuacja tego wymaga oraz dla własnej wygody. Wydaje się, iż zmiana tej sytuacji nie będzie łatwa"15.
Wyniki sondaży robionych przez Bogdana Zdrojewskiego nie tylko wskazywały ogólną tendencję jednoznacznie wskazującą na rosnące, choć w okresie przed samymi wyborami już ustabilizowane poparcie dla Komitetu Obywatelskiego "Solidarność", ale także realistycznie oceniało przeciwników politycznych. Co ważne, wrocławskie sondaże w miarę dokładnie wskazały frekwencję wyborczą (68\%, w rzeczywistości 62,3\%) ${ }^{16}$. 0bremski po latach komentował: „Bogdan zrealizował te badania w sposób chałupniczy, ale przyniósł nam prawdziwsze wyniki niż np. te uzyskiwane przez Centrum Badania 0pinii Publicznej. Mam za to duży szacunek do Bogdana, chociaż wtedy mu nie wierzyliśmy. Według przeprowadzonych przez niego badań okazało się bowiem, że na pewno zdobędziemy dwie trzecie głosów. Uważaliśmy wtedy, że jest zbyt dużym optymistą"17. Warto dodać, że wyniki sondaży przedwyborczych we Wrocławiu były znane również w Poznaniu. Przewodniczący Komitetu Obywatelskiego "Solidarność” w Poznaniu, rektor Uniwersytetu im. Adama Mickiewicza profesor Janusz Ziółkowski, wspominał, że wyniki sondaży Zdrojewskiego były znane, lecz uznawano je za zbyt optymistyczne ${ }^{18}$.

Podobny sondaż, ukazujący mechanizm głosowania w tych wyborach na kandydatów strony opozycyjnej, przeprowadzono w okręgu wyborczym Warszawa-Mokotów ${ }^{19}$. Jego celem było sprawdzenie szans kandydatury Andrzeja Miłkowskiego. Z punktu widzenia marketingu wyborczego w chwili startu Miłkowski skazany był na całkowitą porażkę. Był kandydatem przywiezionym w przysłowiowej

15. Ibidem.

16. Ibidem.

17. Zob. http://dokumenty-przelomu.pl/wywiady/\#_Toc5555889 (dostęp: 28.12.2019).

18. 1989 lipiec, b.d.d., Poznań - Projekt pisma prawdopodobnie Naczelnika Wydziału II WUSW w Poznaniu do Naczelnika Wydziału I Departamentu II MSW w Warszawie w sprawie spotkania delegacji Komitetu Obywatelskiego "Solidarność” z Madeleine Albright w trakcie jej wizyty w Poznaniu, [w:] Wybory czerwcowe 1989 r. w województwie poznańskim. Wybór dokumentów, wstęp i red. Ł. Komorowski, wybór i oprac. dokumentów H. Budzyńska, A. Chmielewska-Metka, R. Czajkowski, P. Drzymała, Ł. Komorowski, Poznań 2019, s. 179.

19. J. Moskalewicz, Przedwyborczy sondaż "Solidarności" w okręgu Warszawa-Mokotów, [w:] Wyniki badań - wyniki wyborów..., s. 63-74. 
teczce, pochodził ze Śródmieścia, pracował w $\mathrm{Hu}$ cie Warszawa na Żoliborzu, a kandydowanie na Mokotowie zaskoczyło również jego samego. Jego kontrkandydatami byli: Zdzisława Guca, rozpoznawalna spikerka telewizyjna z „Panoramy Dnia”, Bogusław Kaczyński, znawca muzyki klasycznej, osobowość telewizyjna, Janusz Zabłocki, poseł, polityk związany z reaktywowanym Stronnictwem Pracy, oraz kilku innych, mniej znanych kandydatów. Sondaż przeprowadzono 19-20 maja 1989 roku na 500 osobach i uzyskano następujące dane. Na dwa tygodnie przed wyborami na udział w nich zdecydowanych było 63\% respondentów. Dalsze $15 \%$ szacowało, że raczej weźmie w nich udział. Razem dawało to $78 \%$ ewentualnych wyborców ${ }^{20}$. Ostatecznie do urn poszło 62,3\% wyborców, co znaczy, że na niemal dwa tygodnie przed wyborami w zasadzie wszystko zostało już rozstrzygnięte, a wyborców niezdecydowanych ostatecznie nie udało się przyciągnąć do urn. Jacek Moskalewicz pisał: "okazało się, że udział w czerwcowych wyborach zapowiedziała zdecydowana większość osób, które wzięły udział we wcześniejszych wyborach do rad narodowych i zaledwie połowa z tych, którzy wówczas nie głosowali. 0 wynikach czerwcowych wyborów przesądzili więc ludzie, którzy poprzednio wybrali do rad narodowych kandydatów PRON-u, a więc gotowi byli do udziału w wyborach niezależnie od stopnia ich demokratyczności"21. Znacznie bardziej intrygujący był fakt, że na dwa tygodnie przed pierwszą turą wyborów Miłkowski był już zdecydowanym faworytem. Chciało na niego gło- sować 49,6\% respondentów, a gdyby dodać do tego $12 \%$ zdecydowanych do głosowania na kogokolwiek z Solidarności, dawało to ponad $60 \%$ szans na zwycięstwo. Pozostali kandydaci uzyskiwali wyniki poniżej 20\%. 4 czerwca Miłkowski uzyskał 71\%, a Guca $18,8 \%$ poparcia ${ }^{22}$. Jak się okazało, także w tym wypadku końcowa faza kampanii nie miała wielkiego wpływu na wyniki wyborów. Miłkowski pozyskał $10 \%$ dodatkowego poparcia, Guca zaś 5\%. Najważniejsze okazało się poparcie Komitetu Obywatelskiego "Solidarność" dla Miłkowskiego, jego cechy osobiste czy program miały drugorzędne znaczenie. Symulacja sondażowa pokazywała jeszcze inny ciekawy trend. 0tóż gdyby brać pod uwagę głosy osób, które deklarowały, że nie będą uczestniczyć w wyborach, lub wciąż się wahały, $z$ biegiem czasu przewaga Miłkowskiego by malała, a przy stuprocentowej frekwencji jego sukces w pierwszej turze byłby problematyczny ${ }^{23}$.

Podsumowując, trzeba ostrożnie stwierdzić, że opinie mówiące o zaskoczeniu, a nawet szoku po obu stronach wyborczej barykady były chyba bardziej teatrem, w którym odgrywano z góry założone role, niż realną oceną wyborczego zwycięstwa. Sondaże wyborcze w obu wypadkach już od przełomu kwietnia i maja coraz jednoznaczniej wskazywały na końcowy wynik. Co więcej, w połowie maja 1989 roku walka była już właściwie rozstrzygnięta. Niewiadomą pozostawał rozmiar zwycięstwa kandydatów opozycyjnych do senatu oraz los listy krajowej, jak się okazało, będącej kluczem do przyszłości kraju...

20. Ibidem, s. 64-65.

21. Ibidem, s. 69-70.

22. Ibidem, s. 70 . 


\section{Bibliografia}

\section{Archiwalia}

Biblioteka Zakładu Narodowego om. Ossolińskich. Dział Rękopisów, sygn. 63/91/1, Badania opinii społecznej 05-10 maja 1989 r.

\section{Opracowania}

Codogni P., Wybory czerwcowe 1989 roku. U progu przemiany ustrojowej, Warszawa 2012.

Dudek A., Reglamentowana rewolucja. Rozkład dyktatury komunistycznej w Polsce 1988-1990, Kraków 2014.

Kisielewski T., Partii portret własny. Polityka i świadomość w PZPR - studium upadku, Warszawa 2012.

Pleskot P., Tam i z powrotem... Georges Mink w słowach, dokumentach i obrazach, Warszawa 2018.

Społeczeństwo $i$ władza lat osiemdziesiątych $w$ badaniach CBOS, oprac. B. Badora, Warszawa 1994.

Wybory czerwcowe 1989 r. w województwie poznańskim. Wybór dokumentów, wstęp i red. Ł. Komorowski, wybór i oprac. dokumentów H. Budzyńska, A. Chmielewska-Metka, R. Czajkowski, P. Drzymała, Ł. Komorowski, Poznań 2019.

Wyniki badań - wyniki wyborów: 4 czerwca 1989, praca zbiorowa pod red. L. Kolarskiej-Bobińskiej, P. Łukasiewicza i Z.W. Rykowskiego, Warszawa 1990.

\section{Internet}

http://dokumenty-przelomu.pl/wywiady/\#_Toc5555889 (dostęp: 28.12.2019).

\section{Abstrakt}

W powszechnej opinii sondaże wyborcze w czasie kampanii z kwietnia-czerwca 1989 roku były tylko domeną obozu władzy. Jak się okazuje, to jeden z kolejnych mitów tego okresu. Swoje sondaże przeprowadzały też Komitety Obywatelskie lub inne organizacje, które starały się odczytać nastroje społeczne tego czasu. W artykule zostają omówione te sondaże, ich wyniki oraz będące ich efektem decyzje podejmowane przez zleceniodawców.
Słowa kluczowe: wybory w PRL, sondaże, kampania wyborcza

\section{Abstract}

The popular opinion stated that the election polls during the April - June 1989 campaign were only the domain of the ruling camp. As it turns out, this is another myth of this period. Citizens' Committees or other organizations which tried to read the social mood of that time also conducted their polls. The article discusses the polls, their results and the decisions made by those who commissioned them.

Keywords: elections in the Polish People's Republic, polls, election campaign

Sebastian Ligarski (ur. 1975) - historyk, dr hab., naczelnik Oddziałowego Biura Badań IPN w Szczecinie. Autor książek: W zwierciadle ogłoszeń drobnych. Życie codzienne na Ślasku w latach 1945-1949 (2007); (z M. Mazurem) Cywilizacja komunizmu. Odmiana nadwiślańska 1944-1956 (2016); (z G. Majchrzakiem) Wojna o eter. Media elektroniczne od "solidarnościowego karnawału" do początków rządów "solidarnościowych" (2016); W kleszczach totalitaryzmów. Księdza Romana Gradolewskiego i ojca Jacka Hoszyckiego życiorysy niedopowiedziane (2017); (z G. Majchrzakiem) Artyści, PRL i bezpieka. Herbert, Miłosz, Hłasko $i$ wielu innych...(2018).

Sebastian Ligarski (b. 1975) holds a PhD in history; he is head of the Department Office of Research of the Institute of National Remembrance in Szczecin. Author of several books: $W$ zwierciadle ogłoszeń drobnych. Życie codzienne na Śląsku w latach 1945-1949 (2007); (co-author with M. Mazur) Cywilizacja komunizmu. Odmiana nadwiślańska 1944-1956 (2016); (co-author with G. Majchrzak) Wojna o eter. Media elektroniczne od "solidarnościowego karnawału" do początków rządów "solidarnościowych" (2016); W kleszczach totalitaryzmów. Księdza Romana Gradolewskiego i ojca Jacka Hoszyckiego życiorysy niedopowiedziane (2017); (co-author with G. Majchrzak) Artyści, PRL i bezpieka. Herbert, Miłosz, Hłasko i wielu innych... (2018). 